\title{
STATE SUPPORT IN PHYSICAL INFRASTRUCTURE UPDATING OF AGRICULTURAL ENTERPRISES
}

\author{
Doctor of Economics, professor Marenich T., \\ Candidate of Economics, associate Professor Zaika S., \\ Candidate of Economics, associate Professor Lutsenko O., \\ Candidate of Economics, associate Professor Polyvana L., \\ Candidate of Economics, senior teacher, Birchenko N.
}

Ukraine, Kharkiv, Kharkiv Petro Vasylenko National Technical University of Agriculture

DOI: https://doi.org/10.31435/rsglobal_ijite/30042019/6453

\section{ARTICLE INFO \\ Received 25 February 2019 \\ Accepted 23 April 2019 \\ Published 30 April 2019}

\section{KEYWORDS}

state support, technical update, budget, leasing, state programs. \begin{abstract}
The basic constituents of state support of technical update of agriculture of Ukraine are considered in the article. The dynamics of expenses of the state budget on agriculture and the structure of basic market levers of state support of physical infrastructure of agricultural enterprises: financial leasing, partial indemnification of domestic agricultural machinery and reduction of prices for credits has been analyzed. Monitoring of current problems of granting and the ways of improvement of mechanism of state support have been offered. No doubt that the proper support from the side of the state is the motive force in activation of the process of technical update of agricultural enterprises.
\end{abstract}

Citation: Marenich T., Zaika S., Lutsenko O., Polyvana L., Birchenko N. (2019) State Support in Physical Infrastructure Updating of Agricultural Enterprises. International Journal of Innovative Technologies in Economy. 3(23). doi: 10.31435/rsglobal_ijite/30042019/6453

Copyright: (C) 2019 Marenich T., Zaika S., Lutsenko O., Polyvana L., Birchenko N. This is an open-access article distributed under the terms of the Creative Commons Attribution License (CC BY). The use, distribution or reproduction in other forums is permitted, provided the original author(s) or licensor are credited and that the original publication in this journal is cited, in accordance with accepted academic practice. No use, distribution or reproduction is permitted which does not comply with these terms.

Introduction. Logistical support of agricultural commodity producers is one of the main terms for development of agrarian production. Providing of agricultural enterprises with the machinery does not satisfy a half from a technological necessity. For the normal update of agricultural equipment and tractor park, it is needed to purchase $8-10 \%$ from a present amount of machines, and taking into account introduction innovative of investment models of development of agrarian industry, 12-15\%. The main reasons through which logistical support of agricultural enterprises of different forms of management doesn't reach the necessary level are the lack of facilities at enterprises, imperfection of credit and depreciation policy and insufficient state support.

Research results. As the analysis proved, the basic constituents of state support of technical update in agriculture of Ukraine in 2002-2019 were [1]:

1) partial indemnification of cost of new machines of domestic production, purchased by the agricultural commodity producers;

2) state leasing fund (budgetary support of operations on leasing of agricultural machines);

3) long-term credits, and also the credits of commercial banks and the personal funds (partial indemnification of interest for to the credits).

The dynamics of expenses of the state budget and ratified volumes of some reasons of charges of the state budget on agriculture is summarized in Tab 1 .

As data in Tabl.1 testify, the general volumes of expenses constantly increased by 15 times, the same dynamics characterizes the expenses on agriculture. At the same time volumes of the state expenses related directly to technical update were utterly unstable. For the period analyzed expenses 
of the Ministry of Agrarian Policy grown twice and arrived at on the average 5.9\%, but their share diminished by 15 times. We will consider and analyze each of constituents.

The program of partial compensation was introduced in 2002 and was provided on a nonrefundable basis at a rate of $30 \%$ of the cost of a complex agricultural machinery of domestic production, excluding VAT, according to the list approved by the interdepartmental expert council on the definition of priorities in the production of machinery and equipment of agricultural producers. The indicated funds were directed to: support of manufacturers of machinery and stimulation of demand from their side.

Access to the $30 \%$ compensation for the cost of agricultural machinery was available for the enterprises that were able to find the financial resources for its acquisition, and its real size was $25 \%$ of the purchase value. At the same time, the authorities restricted the choice of the agricultural enterprises by defining the list and marginal prices for the equipment subject to compensation.

Table 1. Dynamics of financing of budget expenditures for technical renewal of agriculture in Ukraine

\begin{tabular}{|c|c|c|c|c|c|c|c|c|c|c|c|c|c|c|c|c|}
\hline $\begin{array}{l}\text { Budget expendures / } \\
\text { Years }\end{array}$ & ఠิ & ڤ્ণ & ষ্ণ & 究 & \&્ণ & 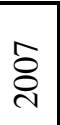 & $\stackrel{\infty}{8}$ & ஓे & $\stackrel{\circ}{\circ}$ & $\bar{\Xi}$ & 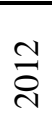 & $\stackrel{m}{\grave{2}}$ & $\stackrel{\nabla}{\grave{i}}$ & $\frac{n}{\grave{i}}$ & $\stackrel{0}{\circ}$ & 홍 \\
\hline $\begin{array}{l}\text { Total budget expenses, } \\
\text { mlrd grn }\end{array}$ & $\begin{array}{l}\infty \\
\dot{m}\end{array}$ & 官 & $\underset{i}{\tilde{N}}$ & $\stackrel{?}{=}$ & ڤ̊ & 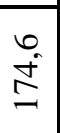 & $\underset{\tilde{n}}{n}$ & $\underset{+}{\stackrel{A}{A}}$ & $\begin{array}{l}0 \\
\vdots \\
0 \\
0\end{array}$ & $\begin{array}{l}0 \\
i \\
i \\
\text { fi }\end{array}$ & 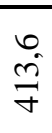 & $\begin{array}{l}n \\
\stackrel{y}{\gamma}\end{array}$ & $\frac{n}{8}$ & $\stackrel{-}{\vec{\infty}}$ & $\stackrel{2}{\frac{1}{G}}$ & 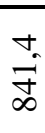 \\
\hline $\begin{array}{l}\text { Ministry of Agrarian } \\
\text { Police and Food } \\
\text { mlrd grn }\end{array}$ & $=$ & $\tilde{n}$ & $\vec{m}$ & $\vec{n}$ & $\stackrel{2}{2}$ & $N^{1}$ & $\overrightarrow{\mathrm{c}}$ & $\hat{\sigma}^{2}$ & $\hat{n}$ & $\stackrel{\forall}{\ominus}$ & $\stackrel{+}{\infty}$ & $\stackrel{+}{\infty}$ & $n$ & $\approx$ & $\stackrel{0}{n}$ & $n$ \\
\hline $\begin{array}{l}\% \text { expendures of } \\
\text { Agrarian Ministry (the } \\
\text { total volume) }\end{array}$ & $\vec{m}$ & $\stackrel{n}{f}$ & $\stackrel{m}{f}$ & $\stackrel{+}{\forall}$ & ñ & $\ddot{f}$ & $\stackrel{\infty}{+}$ & $\stackrel{n}{ \pm}$ & $\stackrel{\infty}{-}$ & $\stackrel{0}{\circ}$ & $\stackrel{0}{i}$ & $\stackrel{m}{i}$ & 8 & 3 & 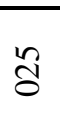 & $\hat{0}$ \\
\hline $\begin{array}{l}\text { Financial support of } \\
\text { agricultural enterprises } \\
\text { through the mechanism } \\
\text { of reduction of prices } \\
\text { of short-long term } \\
\text { credits mlrd grn }\end{array}$ & $\overrightarrow{0}$ & $\tilde{0}$ & $\overrightarrow{0}$ & $\dot{0}$ & $\hat{0}$ & $\ddot{0}$ & $\stackrel{6}{-}$ & $\ddot{0}$ & ' & $\begin{array}{l}n \\
0 \\
0\end{array}$ & & o. & & $\hat{0}$ & $\tilde{0}$ & 3 \\
\hline $\begin{array}{l}\% \text { finsupport through } \\
\text { the mechanism of } \\
\text { reduction of prices of } \\
\text { short-long term credits }\end{array}$ & గू & $\hat{\mathrm{i}}$ & $\stackrel{n}{n}$ & $\hat{\sigma}$ & $n$ & $\vec{\infty}$ & $\begin{array}{l}0 \\
\stackrel{2}{2}\end{array}$ & $\tilde{\nabla}$ & ' & $\begin{array}{l}2 \\
0 \\
0\end{array}$ & & & & $\begin{array}{l}0 \\
\stackrel{-}{=}\end{array}$ & $\stackrel{n}{\simeq}$ & $\stackrel{\infty}{\sim}$ \\
\hline $\begin{array}{l}\text { Partial indemnification } \\
\text { of cost of difficult } \\
\text { technique }\end{array}$ & ?. & $\begin{array}{l}\tilde{O} \\
0 \\
0\end{array}$ & $\theta_{0}^{2}$ & 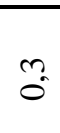 & 0 & $\overrightarrow{0}$ & $\overrightarrow{0}$ & 1 & 1 & $\tilde{0}$ & & & & & & $\hat{0}$ \\
\hline $\begin{array}{l}\text { \% Partial } \\
\text { indemnification of cost } \\
\text { of difficult technique }\end{array}$ & $\stackrel{\infty}{0}$ & $\infty_{0}^{\infty}$ & $\stackrel{0}{=}$ & $\begin{array}{l}\infty \\
i\end{array}$ & $\stackrel{+}{0}$ & $\stackrel{0}{-1}$ & $\stackrel{\infty}{0}$ & , & 1 & $\begin{array}{l}8 \\
0 \\
0\end{array}$ & & & & & & $0^{\circ}$ \\
\hline $\begin{array}{l}\text { Financial leasing of } \\
\text { domestical agricultural } \\
\text { technique }\end{array}$ & $\begin{array}{l}5 \\
0 \\
0\end{array}$ & $\begin{array}{l}8 \\
0\end{array}$ & 1 & 8 & $\stackrel{+}{0}$ & $\overrightarrow{0}$ & 8 & ' & 1 & & & & & & & \\
\hline$\%$ financial leasing & $\overbrace{}^{n}$ & $\stackrel{0}{m}$ & d & $\overrightarrow{0}$ & n? & $\cong$ & 0 & ' & ' & & & & & & & \\
\hline Finance support AIC & & & & & & & & & & & 0 & ò & $\stackrel{2}{0}$ & $\stackrel{n}{0}$ & $\stackrel{O}{O}_{0}$ & 8 \\
\hline \% Finance support AIC & & & & & & & & & & & 0 & $\approx$ & $\rightarrow$ & i & $\cong$ & \\
\hline
\end{tabular}

*Complited by the authors on the basis of laws «State budget» on corresponding year [1].

Considerable experience of application of this program testifies that expenditures on this program substantially varied considerably over the years: with a positive dynamics till 2008, the cessation of financing in 2009, significant reduction in the post-crisis period, and since 2012 through the optimization of 
number of the budgetary programs in one the 'Financial support of measures in an agro-industrial complex', the code of programmatic classification of this program ceased to exist. It was also difficult for many agricultural enterprises to pay $70 \%$ of the cost of complex equipment at once, and it was necessary to look for opportunities to attract long-term loans. The discrepancy between the price and quality of equipment also remained a negative moment. Thus, the buyer compensated the share of expenses for incomplete use of the capacities of the corresponding machine-building plants [2].

However, the results of research conducted by the experts from international organizations confirm the effectiveness and the right to exist of this program; after its reactivation in 2017 it became quite a successful lever of stimulating the acquisition of domestic machinery [3]. During 2017, 134.1 million UAH was absorbed under this program, and 1220 agricultural commodity producers acquired almost 2906 pieces of equipment for the amount of 670.3 million UAH. In 2018, 912.9 million UAH were spent on the compensation of the purchased domestic agricultural machinery which is $(96.6 \%)$ of UAH 945 million of the planned budget [4].

The leaders of this program were the enterprise of Vinnytsia, Odesa, Chernihiv, Dnipropetrovsk, Khmelnytsky, Poltava and Zaporizhzhya regions. Each of them purchased over 500 units of domestic machinery. In addition, from 40 to 115 million UAH of budget indemnification funds was spent in each of these regions.

The State Budget of Ukraine for 2019 provided 25\% compensation for the cost of domestic equipment and $15 \%$ for farms. To this purpose, UAH 881.79 million and UAH 800 million on the development of farms has been allocated. From the specified UAH 800 million, a part of the funds can be used by farms for additional $15 \%$ indemnification of the cost of the equipment. It will allow in future not only to interest agricultural commodity producers in acquisition of domestic machinery but also attract additional funds for domestic machine builders and to improve the quality of machinery.

At the same time, the mechanism of partial indemnification program needs some improvement. Thus, the localization level of $60 \%$ shouldn't be a condition of participation in the program [4]. With the current low level of production quality, it will repel potential buyers. In today's conditions of globalization of markets, a high level of localization can be a consequence of investment attractiveness, ease of doing business, but not a goal. Therefore, the criteria for the level of localization must be abolished altogether or reduced to at least 20-30\%.

It is also necessary to abolish the status of a resident, the criterion of wages level and other requirements as the criteria for selecting producers of equipment, as this considerably reduces the list of participants, eliminates the participation of the enterprise engaged in licensed production and largescale assembling of high-quality foreign machinery, which reduces the attractiveness of participation in the agrarian enterprise program. It is important to establish the criteria for the selection of production and assembling of the machinery and the payment of taxes and fees on the territory of Ukraine, as well as the availability of service warranty and post-warranty service.

The indemnity must be raised to a level not less than $40 \%$ for all buyers, not just farms. Due to the fact that agricultural enterprises prefer high-tech, productive foreign machinery, 25\% indemnification will not be able to fully interest buyers and raise the demand for domestic equipment in the market.

It is also necessary to send partial compensation of the cost of machinery and equipment for the agro-industrial complex directly to enterprises of the domestic agricultural machine-building industry. Under this approach, the following positive changes are achieved: simplification of control over the use of funds and increasing demand for agricultural machinery thanks to the interest of machine-building companies in improving the quality of their products. In addition, customers will not have to pay $100 \%$ of the cost of the equipment at once, and the released funds can be used for other purposes, which will further increase the demand for equipment.

In addition to this, agricultural techniques manufacturers should spend at least half of the profit received from the sale of the equipment under the compensation program exclusively on scientific and technical and engineering design, the introduction of advanced technology and the organization of licensed production.

Another measure of the state was the financing of the purchase of agricultural machinery at the expense of the state budget and its transfer to financial leasing, which is the most widespread in the world practice of forms of financing. In the United States, leasing covers more than a third of all investment. One of the largest tractors in the world, John Deer, an international company, has been leasing more than $50 \%$ of sales in recent years [5]. 
However, the application of leasing in the technical and technological re-equipment of agriculture of Ukraine is unacceptably low. Only $0.2 \%$ of the agricultural equipment available is in leasing. Of about 2 million tractor units and other equipment, which is prepared to go to the field annually, only about 4 thousand units was purchased under the leasing scheme.

The total share of leasing investments in funds spent on the purchase of machinery and equipment of agricultural producers remains insignificant (7.1\%). The appreciation of leasing reduces its attractiveness: in the structure of leasing payments, the remuneration to the lessor has grown by 2 times, compensation for the loan - by 6times, other costs - by 4 times and the reimbursement of the value of the object of leasing, by contrast, decreased by $15 \%$.

The main factor behind the rise in price was the change in the base of charging a one-time fee for organizing the delivery of equipment: at a rate of $7 \%$ of the non-recoverable initial value, whereas previously payment was charged less the previous lease payment for the use of the equipment in terms of reimbursement of its value.

In our opinion, in order to increase the efficiency of this direction of state support, it is necessary to monitor the activities of agricultural machinery manufacturers, who transfer funds for leased equipment and carefully select specific types of equipment according to their quality, improve the conditions for providing leasing services in the direction of reduction of commission fee, to raise qualitative parameters and expand the list of equipment, which is transferred to the leasing, to actively involve small and medium enterprises, including cooperatives and farms.

The financial support of enterprises through the mechanism of cheapening loans (including interest and all expenses related to servicing the loan) was allocated on average 6.5\%. Almost negligible shares for partial compensation of the cost of complex domestic production and financial leasing, which is only $1.5 \%$ of the total expenditures of the Ministry of Agrarian Policy. Of course, such a level of budget financing for the development of agro-industrial production in Ukraine is extremely insufficient and many times less than necessary.

Our research has shown that the program of financial support to the agroindustrial complex through the mechanism of cheapening loans has disadvantages that impede its effective operation. Thus, the significant disadvantage of the investigated mechanism is the discrepancy of some areas of the targeted use of preferential loans with economically justified terms of crediting. The low profitability of agrarian business does not allow to recover most of the prescribed mechanism of medium-term financing of expenses up to 3 years. In our opinion, $80 \%$ of agricultural enterprises need long-term crediting from 5 to 20 years, and $20 \%$ - from 1-3 years.

The mechanism of partial indemnification of credits is not fully used, through a refuse in the grant of credits to the unprofitable enterprises, even at presence of mortgage and mortgage requirements to providing of credits [6]. Also, the main condition for obtaining a loan should be the possibility of its timely repayment, but not a competitive basis.

Consequently, the bank crediting so far did not play a considerable role in the development of agricultural industry. The bank crediting while did not play a considerable role in development of agricultural industry. However, much positive tendencies are noticeable in relation to growth of volumes of crediting from the side of domestic commercial banks, including concessional lending.

The analysis of volumes of the budgetary financing testifies that with their growth the amount of the purchased machinery was increased. Budgetary support of all market levers, which was instrumental in the increase of volumes of acquisition of technique, had the positive enhanced effect ( $\mathrm{a}$ coefficient of correlation between the selected facilities and amount of the purchased equipment was 0.872). In 2003-2012 the share of the purchased domestic machinery with partial indemnification its cost was $20 \%$, financial leasing- approximately $22.4 \%$, and concessional lending - 26.5\%. In our view, these figures are convincing enough to lead to expedience of state support. In separate years some programs were not financed sufficiently, that diminished the amount of acquisition of agricultural machinery by many times.

Certainly, the mechanism of granting indemnifications in all the programs needs improvement. The main drawbacks include: limited financial capacity of agricultural producers, small volumes and unevenness of state budget revenues, and the risk of a large part of budget programs through their financing from the special fund. It should also be noted that the structure of budget financing for the development of physical infrastructure is not stable. 
The budget financing of the agroindustrial complex is characterized by a variety of varieties and its incomparability over the years. For example, programs that operated during 2003-2011 under the program classification 28002240 'Implementation of financial support of agribusiness enterprises through the mechanism of cheapening loans', 2801430 'Partial indemnification of the cost of complex agricultural machinery of domestic production', as well as 2801490 'Measures on financial leasing operations of domestic agricultural machinery', in the state budget of 2012 and 2013 were consolidated into one budget program KPKV 2801180 'Financial support of measures in the agroindustrial complex', and its planned volume decreased by 8.5 times.

In our view, the association of several programs into one greatly complicates the control over the implementation of the principle of the targeted use of budget funds; creates opportunities for abuse; does not ensure the efficiency of the use of public resources. We can also argue that insufficient funding, uneven allocation of funds, lack of transparency in the selection of participants and an imperfect procedure for allocating budget funds aimed at partially offsetting the cost of difficult agricultural machinery of domestic production did not make it possible to realize all the benefits of this state support program as a mechanism of partial stimulation by the state demand for agricultural machinery from private capital.

For efficient use of budget funds for targeted programs, the support should be carried out in a complex manner, which involves budget financing within several interdependent programs at the same time, as the lack of funding or underfunding of one of the programs can lead to the disruption of the entire technical chain and lead to non-implementation of the entire program.

Conclusions. In general, the amount of financing of the State Target Program on the implementation of technical policy in the agro-industrial complex for the period till 2021year at the expense of the state budget at the level of $7.6 \%$ were not implemented and are constantly violated [7].

The analysis of the existing order of state support for the technical update of agrarian production shows the need for its improvement. Particular attention should be paid to its extremely limited volume.

For the improvement of mechanism of national support it is expediently:

- to determine the criteria of distributing of budgetary funds;

- to introduce a mechanism for the participation of agricultural producers in state financial support programs on the basis of equal access and effective use of funds;

- to increase the amount of financing and implement the relevant control system;

- to promote the efficiency of budget expenditures to support the agrarian sector of the economy by introducing a program-target method for the formation and use of budget funds;

- to monitor the implementation of budget programs, which will result in the cancellation of ineffective programs and direct financial resources to implement programs that are most in line with the objectives of state support.

\section{REFERENCES}

1. Rozpodil vydatkiv derzhavnogo biudzhetiv za 2003-2017roku. Retrieved from: http: // w1.c.1.rada.gov.ua/pls/zweb2/webproc34?id=pf3511=41157 [in Ukrainian].

2. Marenich, T.G., Lutsenko O.A. Derzhavne rehulivvannia tekhtichnogo onovlennia silskohospodarskih pidpryiemstv, 2012 [State regulation technical renovation of agricultural enterprises]. Kharkiv.Visnik, 104,KhNTUSH, pp.31-40[in Ukrainian]..

3. Monitoring i otsinka silskogospodarskoyi polityku [Monitoring and estimate of agrarian police]. Retrieved from: http: //www.stat.oecd.org.

4. Zakharchuk O.V. Tekhnichne zabezpechennya silskogospodarskyh pidpriemstv v Ukraini, 2019 [Nechnical maintenance of agricultural enterprises in Ukraine].Economika APK, 2, pp.48-55 [in Ukrainian].

5. Nukutchenko Yu.V. Lizing v Ukrayini i SSHA: spilne i vidminne, 2015 [Leasing in Ukraine and the USA : general and different], Investitsiyi: praktika ta dosvid, 7, pp. 57-77.

6. Dem'yanenko M.Ya. Finansovi problemu formuvannya ta rosvytku agranogo rynku [Finansial problems of formation and development of agrarian market], 2007. K. NNTS, 64p. [in Ukrainian].

7. Proekt Derzhavnoi tsilovoi prohramy rozvytku agrarnoho sektoru economiky na period do 2021 roku [Draft state target program for development of the agrarian sector for the period up to 2021]. Retrieved from: http: // minagro.gov.ua/ apk?nid=24198iu [in Ukrainian]. 